\title{
Facebook Addiction among Afghan University Students: A Structural Equation Modelling
}

\author{
Hassan Rahnaward Ghulami, Abdul Samad Roesh, Mohammad Reza Ibrahim, Mohammad \\ Akbari, Hossein Mohammadi
}

\begin{abstract}
The current research intends to evaluate the validity and reliability of the adopted model-BFAS, and investigate relationship between the motives and Facebook addiction in Afghanistan. The adopted instrument were online distributed to undergraduate and postgraduate students and only 431 responded across the country to determine their intentions for using Facebook. The software of RStudio used for descriptive analysis and SEM-PLS approach was applied to hypothesis the relationship between the constructs. Results showed that the BFAS measures intensity of Facebook addiction, although measurement model was reliable and structural model has discriminate validity. Further, the results show that students use Facebook for communication, social interaction and entertainment, and these motives positively predicted Facebook addiction. Based on the results, authors believe that the Facebook addiction is a phenomenon that exists across the countries, and greater use of Facebook would tend to create problem of addiction. In sum up, this research would help parents, serves provider, policy makers, current Facebook users, and students to control their excessive use of Facebook.
\end{abstract}

Keywords: Facebook; Addiction; SEM; Motives

\section{INTRODUCTION}

$\mathrm{F}_{\mathrm{a}}$ Mark Zuckerberg along with Edward Saverin, and it's began in February of 2004. Nowadays, after 17 years of existing, Facebook has become the largest user friendly social network website and global phenomenon [1], [2]. Currently, there are over 2.8 billion monthly users worldwide are active participants in the communities (Facebook, 2021) as of

Manuscript received on 15 March 2021 | Revised Manuscript received on 22 March 2021 | Manuscript Accepted on 15 April 2021 | Manuscript published on 30 April 2021.

* Correspondence Author

Hassan Rahnaward Ghulami*, Mathematics Department, Faculty of Natural Science, Bamyan University, Bamyan, Afghanistan. Email: Hassan.r.gh@bu.edu.af

Abdul Sammad Roesh, Physics Department, Faculty of Natural Science, Bamyan University, Bamyan, Afghanistan. Email: samadzarin37@gmail.com

Mohammad Reza Ibrahim, Sociology Department, Faculty of Social Science, Bamyan University, Bamyan, Afghanistan. Email:rezaibrahim.ibrahimi@gmail.com

Mohammad Akbari, Mathematics Department, Faculty of Natural Science, Bamyan University, Bamyan, Afghanistan. Email: bamianzarin@gmail.com

Dr. Hossein Mohammadi, Agronomy Department, Faculty of Agriculture, Bamyan University, Bamyan, Afghanistan. Email: Mohammadi8888@gmail.com

(c) The Authors. Published by Lattice Science Publication (LSP). This is an open access article under the CC-BY-NC-ND license (http://creativecommons.org/licenses/by-nc-nd/4.0/)
March, 2021. It is broadly using worldwide for many different reasons like; using for academic purposes and it is a machine learning tools [3], [4], it is a dynamic marketing and business tools [5], [6], it is an intensive social communication tools for finding ways to connect with friends, family members, classmates, scholars and so on [7], and it is one of the best places where we can find manifestation of feelings [8]. Nowadays, the learning process increasingly involves informal learning by information technology, and Facebook endure to excite scholars and educators to explore its educational use [9]. In terms of social reason, the users of Facebook have communities and groups of people that they are able to create a public or semipublic profile, chatting, create groups, send private messaging, and share posts, among others in order to keep in touch with family members, friends, classmates and world happenings [10]-[13]. As for as marketing and business tools, many organizations, companies, and institutions created Facebook accounts to promote for their trade, industries and businesses among the target populations [10], [13].Nowadays Facebook has become a global phenomenon and being one of the best and greatest importance communication tools among students and youth generation. According to Zarmohzzabieh [14] university students being logged in Facebook for entertainment, maintaining existing relationship, and passing time. The finding show that the Facebook user has increased the scope of higher education [15], research methods [16] and friendship facilitation over the past years [17]. In college and university, the students are the most prolific social network user [18]. According to Allen [19] Facebook user get huge attention due to the educational emphasis on technology, and it is indeed a valid research tools to administer the social, health psychometric and so on researches [20], [21]. Further, Facebook is the best platform for training and contact with friends and scholars [10], [11], [17]. Although Facebook can promoted active learning [22], enhance students' engagement [23], support knowledge structure [24], [25], and be used as a communication tool consistent with the favorite of today students [26]-[29]. Many studies stated that more than $92 \%$ of students using Facebook and spending her/his time to be logged on this site [9], [15], [19], and [27]. The finding of many studies shows that there are five main academic use of Facebook which are: (1) Support class discussions and helping students engage in collaborative learning; (2) Developing content; (3)

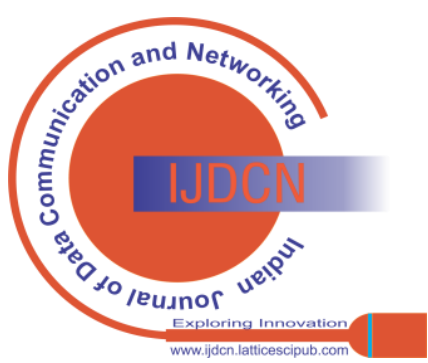


Sharing educational resources; (4) Delivering content to expose students to extra-curricular resources; and (5) To support self-managed learning [15], [19], [23], [27], [30], [31].

Further, it's also reported that students can use Facebook for other purposes like improvement in English language knowledge such as writhing, reading, speaking and vocabulary [27], [32].

As reported by Social Media Stats in Afghanistan-March 2021, the number of Internet and social media users in the Afghanistan is forecast to increase to approximately (17\%) of Afghanistan population [23] and the most social media user was in big cities. Facebook is by far the most popular social media website in the Afghanistan, and approximately (87.56\%) of the Afghan social media user were using Facebook [33]-[35], followed by Twitter (4.30 \%), YouTube (3.49\%), Pinterest (2.80\%), Instagram (0.30\%), Google+ (0.28\%) and so on. According to [33] Afghans students have more access Internet to use Facebook in libraries, learning centers, cultural centers, bookstores and universities campuses [35], [36]. Likewise it's founded that the students and youth generations Facebook user experienced some negative effects of excessive Facebook usage and already captured "Addiction". Although, abuse and excessive usage of Facebook is significant public health problems globally [9], [14], and the use of Facebook has now become a dominant discourse among Afghan university students [35]-[38]. Although, the large number of Afghan university students and youth engagement use Facebook and their quantity of his/her time that they are spending for cyberspace, spending leisure time for online gaming, share the information and other interaction activities [35], [36], [39].

In recent years, it has been recognized that the Facebook Addiction has become the considerably more important. Several studies have been conducted on this topic [12], [17], [28], [40], [41], [41], [42]. It is reported that Facebook addiction has become a universal concern and considered as a health issue [43], although it has been a worldwide problem among university students and youth generation [2], [10], [17], [28], [40], [42], [44]. It is clear that the symptoms of Facebook addiction can be exhibited in attitudes [45], cognition [46], physical and emotional reaction [47], and interpersonal and psychological problems [7], [34], [44], [48]. Although, those who addicted in Facebook and other social media facing with many challenges such as skipping sleep, feeling anxiety, stressed, ignoring family responsibilities, showing up late in academic performance and professional works [34], [40], [44]. Further, these are evidences of physical and psychological disorder which meet up with the criteria for impulse control disorder, mental illness characterized by an uncontrollable desire to perform behavior [17], [40], and [42]. Moreover, there are very limited studies conducted regarding Facebook addiction in Afghanistan; therefore, it is important to conduct a study in order to fill this gap. So, it is expected this work tries to Afghan university students and youth engagement via explore Facebook addiction model and its predictor among

Structural Equation Modeling (SEM) approach. Further, this research is aimed to evaluate the validity and reliability of the adopted model-BFAS, with in Afghan student's sample. The objective of the study is to investigate the motives that encourage Afghan students to fulfill their desires through Facebook addiction.

\section{LITERATURE AND HYPOTHESES DEVELOPING}

\section{A. Facebook User}

There are many reasons why students and youth generations use Facebook. Facebook user population worldwide has increased dramatically from 100 million in 2008 to 2.8 billion monthly active users as and Approximately 1.85 billion daily active users on average for March 2021 (Facebook, 2021). According to Facebook newsroom in 2021, about 4.45 million Facebook monthly active user in Afghanistan which accounted for $11.4 \%$ of its entire population. According to [27] of all social media users, 92\% use Facebook, while $71 \%$ of all adult internet users use Facebook. A number of studies have founded many motives to visit Facebook which are professional advancement [4], [31], [49], [50], entertainment and relaxing [10], [51], social interaction with existing friends and family [10], [52], relationship maintenance [53], virtual community and communication [10], companionship [54], escapism [55], meeting new people [30], [56], expressive information sharing and getting information about any events [57], and so on. Afghan students also have used Facebook for different purposes such as personal life, passing time, learning, sharing information, political arena and so forth [33], [37], [38]. The finding of studies show that students spend a huge partial of their daily time on Facebook and other social media rather than concentrating on their academic activities [35], [37], [38].

\section{B. Facebook Addiction}

Facebook have become extremely and increasingly popular among learners. The excessive use by individuals has led to the emergence of the concepts of Facebook addiction [41], [42], [42], feeling anxious [43], [58], got depression [59], [60], body image and disordered eating [61], drinking cognition and alcohol use [62]. The concept of addiction is not easy to define, but central to it is dependence on a substance or daily activities. Dependence is characterized by overindulgence, tolerance, withdrawal, craving, and loss of control [34]. Several studies have reported that the Facebook addiction is a common problem among students and youth generations [24], [24], [40], [42], [44]. Although, Facebook addiction had received slightly consideration in the literature and founded that Facebook addiction have positive correlation with Facebook motives such as entertainment, communication and social interaction [10], [17], [40], [44], [58], [63], [64].

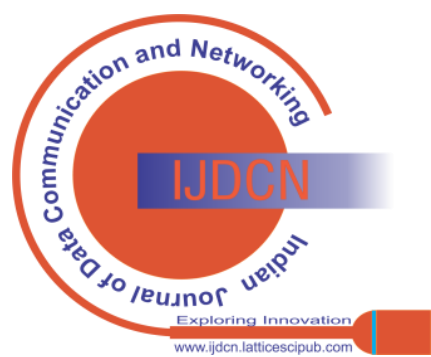


Further, its argued that the Facebook addiction is related with being male, being a heavy Facebook user [65], being in a higher year level at university [24]. The finding of [10] is showed that the three constructs such as social interaction, entertainment and communication were predictors of Facebook addiction.

\section{Facebook as a Communication tools}

Facebook operates primarily as a tool for communication among university students and youth engagement in Afghanistan [33], [35], [36]. By using the Facebook, the students able to share any information regarding their academic activities [4], [15], [19], class notes and assignments [56]. Although, the results of many research show that communication professionals appreciate social media, particularly Facebook for the ease and speed with which information can be accessed and delivered [66]-[68]. Although, communication motive encourage users to stay in touch to post a comment on his/her friend's wall, send messages to friends, sharing information on his/her wall, chat with friends, build network with others, and get gossip about others[44], [63], [69]. Communication was found to be motive for using Facebook among students and were the strong predictor of Facebook addiction [10], [63], [70], [71]. Further, it can be inferred that communication motive will influence the Facebook addiction, social interaction and entertainment, because communication was the most frequently cited motive for using Facebook. Thus, we hypothesize that:

H1: Communication will have a positive effect on Facebook Addiction.

H2: Communication will have a positive effect on Social interaction.

H3: Communication will have a positive effect on entertainment.

\section{Facebook as an Entertainment tools}

Another important motive for massive using Facebook is entertainment. They were numerous of interactive features offered by Facebook such as games, notes, photographs, videos available on Facebook which enable users to relax and have fun [25], [63], [69]. Although, literature shows that most of students use Facebook for fun and entertainment [10], [24], [69]. However, entertainment and passing time were most frequently Facebook use to share fun and enjoyable [24], content and photo sharing [72], upload materials and social relation [10], [24]. The finding of studies carried out that entertainment motive was significantly and positively predicted Facebook addiction [10], [25], and [63]. Thus, we hypothesize that:

\section{H4: Entertainment will have a positive effect on Facebook} addiction.

H5: Entertainment wil65l have a positive effect on social interaction.

\section{E. Facebook as tool for Social Interaction}

As founded that Facebook is effective socialization tool rather than social media. Many students used Facebook to stay in touch and build social ties in terms of maintain old and existing friendship, share recent activities with friends, checking invitation wedding party and birthday from friends [65], [73], [74]. According to [69] the social interaction motive encourage students to excessive using Facebook for personal self-disclosure. Although, excessive users may be partly relapsed and attributed to an increasing overdependence on Facebook as meaningful social interaction and may increase the risk of addiction [72]. Several studies found that the social interaction motive to be a major for using the Facebook and it have significantly relationship with Facebook addiction [10], [63]. Thus, we hypothesize that:

H6: Social interaction will have a positive effect on Facebook addiction.

\section{METHODS}

\section{A. Sampling}

To achieve the study objectives, adopted quantitative method via online survey conducted to collect data the relevant information related to the issues of the study. Google form was used to collect data, and link of the survey shared on Facebook walls and other social media groups. The feature of the current study required data to collect from present and graduated students inside and outside of Afghanistan. The sample was selected on the basis of convincing sampling method between November and December 2020. Data was collected from 431 individuals, aged from 18 to 38 years. Most participants were males (76 \%), also the majority of individual's status were single (52\%), having completed their bachelor's degree (60\%), Masters (35\%), and Ph.D (5\%), (see Table 1). The current sample was considered sufficient which the application SEM approach to address the research objective and testing the hypotheses [75]-[77].

\section{B. Measurement}

Specifically, the instrument designed for the current study included three parts which are: first, sociodemographic characteristics gender, age, status, background and level of study, and GPA. Second, the constructs of communication, entertainment, and social interaction which consist of 17 items was adopted from [10], [69], and [78] to investigate students' motives for Facebook use. And third, the adopted widely used Bergen Facebook addiction Scale (BFAS) developed by [79] is used to measure an individual's level of Facebook addiction. The adopted BFAS is included six constructs(conflict, mood-modification, relapse, salience, tolerance, and withdrawal) with 18 item self-report inventory which is covering the problems created by excessive use of Facebook, each item is scored on a five-point likert scale from ( $1=$ Very rarely to $5=$ Very often); and asked from participants to indicate their agreement/disagreement on these items. The higher scores indicate greater Facebook addiction. The instrument has acceptable reliability $(\alpha=0.74)$ for targeted population (see Table 2).

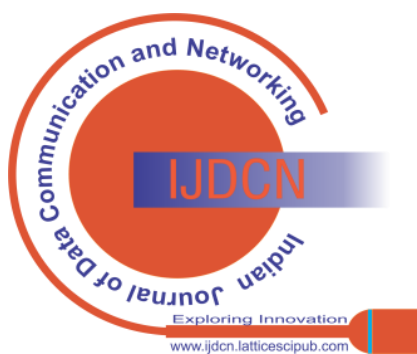




\section{Statistical Analysis}

The collected data was analyzed with regard to the objectives of the study using RStudio-1.3.1093 for descriptive analysis and SmartPLS-3 software was used to test the hypothesis model using Structural Equation Model- Partial Least Squares (SEM-PLS) [76]. To test the measure model (validity and reliability of measures), next by an examination of the structural relationships between the existing constructs (testing the hypothesized relationship) [76], [80], [81]. As well, the significance of path coefficients and the loading a bootstrapping method (5000 resamples) was used [76], [81], and [82].

\section{RESULTS}

Based on the objectives of the current study, the SEM-PLS statistical approach were employed for testing the hypotheses. This section will presents and discusses the finding and tabulate the results.

\section{A. Reliability and Validity of Measurement Model}

Relationship between the motives constructs, Facebook addiction scales and indicators were assessed for the reliability and validity of measurement model using PLS approach [76], [80], and [83]. In this case, four common measures recommended by

Table 1: Participant's demographic characteristics by Gender

\begin{tabular}{llccc}
\hline Factors & Levels & Total (n=431) & Males (76\%) & Females (24\%) \\
\hline \multirow{2}{*}{ Age (years) } & $18-22$ & $83(19 \%)$ & $57(13 \%)$ & $26(6 \%)$ \\
\cline { 2 - 5 } & $23-28$ & $173(40 \%)$ & $120(28 \%)$ & $53(12 \%)$ \\
\cline { 2 - 5 } & $29-33$ & $87(20 \%)$ & $69(16 \%)$ & $18(4 \%)$ \\
\hline \multirow{2}{*}{ Status } & $33-38$ & $88(21 \%)$ & $82(19 \%)$ & $6(2 \%)$ \\
\hline \multirow{2}{*}{ Universities } & Married & $208(48 \%)$ & $183(42 \%)$ & $25(6 \%)$ \\
\cline { 2 - 5 } & Single & $223(52 \%)$ & $145(34 \%)$ & $78(18)$ \\
\cline { 2 - 5 } & Abroad University & $111(26 \%)$ & $87(20 \%)$ & $24(6 \%)$ \\
\cline { 2 - 5 } & Bamyan University & $105(24 \%)$ & $78(18 \%)$ & $27(6 \%)$ \\
\cline { 2 - 5 } & Shahid-Rabani-University & $16(4 \%)$ & $12(3 \%)$ & $4(1 \%)$ \\
\cline { 2 - 5 } & Kabul-Polytechich University & $10(2 \%)$ & $9(2 \%)$ & 1 \\
\cline { 2 - 5 } & Kabul University & $73(17 \%)$ & $50(12 \%)$ & $23(5 \%)$ \\
\cline { 2 - 5 } & Nangarhar University & $17(4 \%)$ & $14(3 \%)$ & $3(1 \%)$ \\
\cline { 2 - 5 } & Takhar University & $7(2 \%)$ & $7(2 \%)$ & 0 \\
\cline { 2 - 5 } & Others Universities & $92(21 \%)$ & $71(16 \%)$ & $21(5 \%)$ \\
\hline \multirow{2}{*}{ Discipline Studied } & Science and Technology & $230(53 \%)$ & $170(39 \%)$ & $60(14 \%)$ \\
\cline { 2 - 5 } & Social Science & $201(47 \%)$ & $158(37 \%)$ & $43(10 \%)$ \\
\hline Level of Study & Bachelor's Degree & $259(60 \%)$ & $185(43 \%)$ & $74(17 \%)$ \\
\cline { 2 - 5 } & Master's Degree & $149(35 \%)$ & $122(28 \%)$ & $27(6 \%)$ \\
\cline { 2 - 5 } & Philosophy & $21(4 \%)$ & $2(1 \%)$ \\
\hline
\end{tabular}

Table 2: Constructs Reliability and validity

\begin{tabular}{|c|c|c|c|c|c|}
\hline Constructs & Items & $\begin{array}{c}\text { Factor } \\
\text { Loading }\end{array}$ & Cronbach's Alpha & CR & AVE \\
\hline \multirow[b]{5}{*}{ Communication } & Q2-Com2 & 0.64 & & & \\
\hline & Q4-Com4 & 0.57 & & & \\
\hline & Q5-Com5 & 0.72 & & & \\
\hline & Q6-Com6 & 0.76 & & & \\
\hline & Q7-Com7 & 0.72 & 0.72 & 0.82 & 0.47 \\
\hline \multirow[b]{5}{*}{ Social Interaction } & Q13-S-In1 & 0.66 & & & \\
\hline & Q14-S-In2 & 0.7 & & & \\
\hline & Q15-S-In3 & 0.69 & & & \\
\hline & Q16-S-In4 & 0.71 & & & \\
\hline & Q17-S-In5 & 0.59 & 0.69 & 0.8 & 0.45 \\
\hline \multirow[b]{5}{*}{ Entertainment } & Q8-Ent1 & 0.67 & & & \\
\hline & Q9-Ent2 & 0.77 & & & \\
\hline & Q10-En3 & 0.81 & & & \\
\hline & Q11-Ent4 & 0.54 & & & \\
\hline & Q12-Ent5 & 0.62 & 0.72 & 0.82 & 0.48 \\
\hline \multirow[b]{6}{*}{ Facebook Addiction } & Conflict & 0.75 & & & \\
\hline & M-Modification & 0.67 & & & \\
\hline & Relapse & 0.76 & & & \\
\hline & Salience & 0.74 & & & \\
\hline & Tolerance & 0.8 & & & \\
\hline & Withdrawal & 0.73 & 0.84 & 0.88 & 0.55 \\
\hline
\end{tabular}




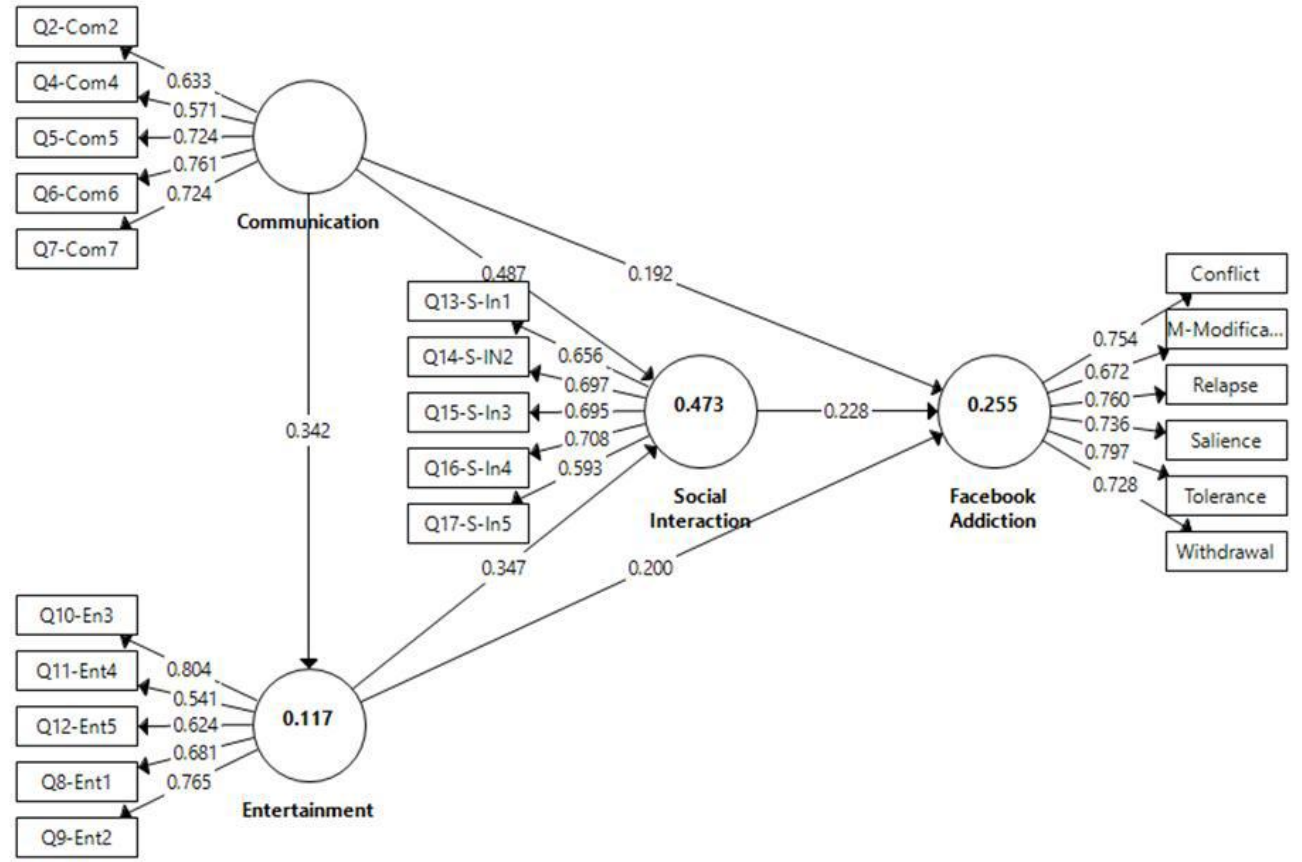

Fig.1. Measurement Model

- [76], [80], [83] which are; factor loadings, Cronbach's Alpha, composite reliability (CR), and average variance extracted (AVE).

The under investigated constructs validity of the adopted model assessed by examining the respective factor loading, while it has been recommended the cut-off value for factor loading is higher than 0.50 , and it is considered significant [76], [84], [85]. As shown in Table 2 and Figure 2, the factor loading of observed items which are measuring the particular constructs are gather than recommended cut-off value and ranged from (0.54 to 0.81), thus confirming constructs validity.

Further, the most common measurements Cronbach alpha and CR were used to examine the reliability based on the interrelationship between the observed constructs [76], [80], [83], [84]. In PLS-SEM, the values of Cronbach alpha and CR between ( 0.60 to 0.70$)$, are acceptable [83], [84]. In order to increase the values of $\mathrm{CR}$ in the reflected constructs of measurement model two items form Communication (Q1-Com1, Q3-Com3) were deleted [83]. After the deletion, the $\mathrm{CR}$ for all the constructs are greater than the recommended cut-off values (see Table 2 ).

Furthermore, by way of mentioned above, the convergent validity was assessed in terms of AVE and the value should be exceed 0.50 , that adequate for convergent validity [80], [84]. It is reported that the high values shows that the constructs are measuring the predicted concept [80]. In this case, Table 2 shows that the only one construct (Facebook addiction) score of AVE were above 0.50 except for others; communication, social interaction and entertainment constructs $(0.47,0.45$, and 0.48 ; respectively). Thus, it can be not too much concern to say that there are no validity problems, because the mentioned values almost 0.50 . Finally, it is confirming that the measurement model has a convergent validity.

\section{B. Discriminant validity}

In this case, the criterion of Fornell-Lacker has used to assess discriminant validity (DV) [86]. This approach compares the square root of AVE with the correlation between the measures of potential latent constructs [84], [85]. According to Dhaha [10], the DV is achieved when AVE is greater than the square of correlation between the two latent constructs. The output of correlation coefficients between the latent constructs has been shows in Table 3. Referring to Table 3, all the values of square root of AVE (values in bold) and correlations between constructs (off-diagonal) are greater than the correlations in the relevant columns and rows. Overall, it is easy to say that the current measurement model demonstrated acceptable discriminant validity.

Table 3: Discriminant validity

\begin{tabular}{|llllll}
\hline Latent Constructs & AVE & A & B & C & D \\
\hline Communication (A) & 0.47 & $\mathbf{0 . 6 9}$ & & & \\
\hline Entertainment(B) & 0.48 & 0.34 & $\mathbf{0 . 6 9}$ & & \\
\hline Facebook Addiction (C) & 0.55 & 0.40 & 0.38 & $\mathbf{0 . 7 4}$ & \\
\hline Social Interaction (D) & 0.45 & 0.60 & 0.51 & 0.45 & $\mathbf{0 . 6 7}$ \\
\hline
\end{tabular}

\section{Hypothesis Testing}

To assess this structural model for examining the hypothesized model between latent constructs has been suggested by Hair et al. (2020) to looking the standardized beta coefficient $(\beta)$, coefficient of determination $\left(R^{2}\right)$, and path coefficient (t-value) via a bootstrapping method with resampling of 5000 [81]. The $\beta$ compares the strength of the effect of each individual independent construct to the dependent construct [37], [82]. As asserted by [82], while $R^{2}$ are used in order to find the amount of variance in each endogenous latent construct, which are described by the model. The others measures such predictive relevance $\left(Q^{2}\right)$ and effect sizes $\left(f^{2}\right)$ should be report by researchers as well.

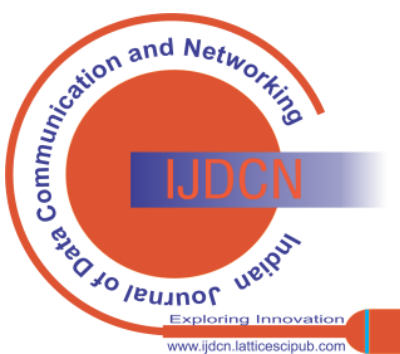


In PLS-SEM approach, $Q^{2}$ obtaining by blindfolding calculation and it is a synthesis of function fitting and cross-validation, and $Q^{2}$ greater than zero are considered that the structural model have predictive relevance. As stated by many studies that the statistical significance (p-value), and substantive significance $\left(f^{2}\right)$ are used to measure the changes in $R^{2}$ to understand that the dependent and independent constructs have practical impact [80]-[82]. As suggested that the effect is large when $f^{2}=0.35$, medium when $f^{2}=0.15$, and small when $f^{2}=0.03$.

Table 4 and Figure 2 present that the communication ( $\left.\beta=0.49, t=13.19, p<0.05, R^{2}=0.473\right)$ and entertainment $\left(\beta=0.35, \quad t=8.09, \quad p<0.05, \quad R^{2}=0.473\right)$ positively influenced social interaction, which implies that $47.3 \%$ social interaction predicted by communication and entertainment. This gives support for $\mathrm{H} 2$, and $\mathrm{H} 5$. Further, communication ( $\beta=0.34, t=7.37, p<0.05, R^{2}=0.0 .117$ ) were significant, while communication explaining $11.7 \%$ of the variance in entertainment and H3 supported. Next we looked at the predictive effects of the Facebook addiction. Furthermore, the Communication $(\beta=0.19, t=3.57, p<0.05$, $\left.R^{2}=0.255\right)$, social interaction $(\beta=0.23, t=3.57, p<0.05$, $\left.R^{2}=0.255\right)$, and entertainment $(\beta=0.20, t=4.09, p<0.05$, $R^{2}=0.255$ ) were the significant predictors of Facebook addiction and explaining $25.5 \%$ of the variance in addiction. The findings support H1, H4, and H6. From this analysis, all hypothesized relationship are supported at $(p<0.05)$.

The result indicated $Q^{2}>0$, thus the adopted model must be able to provide a prediction of endogenous constructs. Table 4 shows that communication on Facebook addiction has large effect; while entertainment on social interaction has medium effect, and others have small effect on the adopted mode.

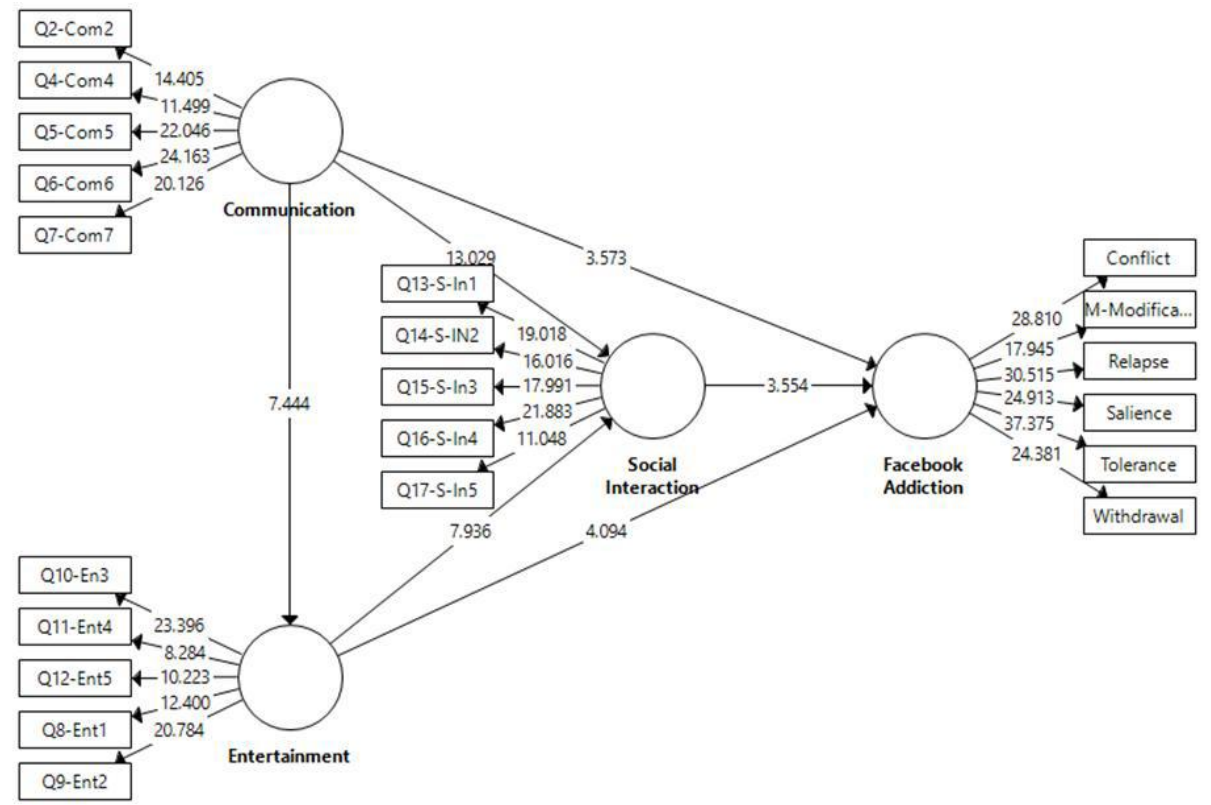

Fig.2.Structural Model

Table 4: Results of hypotheses testing

\begin{tabular}{llccccccc}
\hline Hypothesis & Relationship & $\beta$ & SE & T-Value & Decision & $R^{2}$ & $Q^{2}$ & 0.03 \\
\hline H1 & Comm -> FA & 0.19 & 0.05 & 3.55 & Supported & 0.255 & 0.13 \\
H2 & Comm -> So-In & 0.49 & 0.04 & 13.19 & Supported & 0.473 & 0.21 \\
H3 & Comm-> Ente & 0.34 & 0.05 & 7.37 & Supported & 0.117 & 0.13 \\
H4 & Ente -> FA & 0.2 & 0.05 & 4.09 & Supported & & 0.04 \\
H5 & Ente -> So-In & 0.35 & 0.04 & 8.09 & Supported & & 0.2 \\
H6 & So-In -> FA & 0.23 & 0.07 & 3.54 & Supported & & 0.04 \\
\hline
\end{tabular}

\section{DISCUSSION AND CONCLUSION}

To sum up, Afghan students' motives for Facebook use have become the important influences to Facebook addiction. Likewise, Afghan students extremely used Facebook for these three following motives; communication, social interaction, and entertainment. Although, this study is required to determine the three above mentioned motives effect on Facebook addiction. Our finding show that the mentioned motives predicting Facebook addiction and interrelationship between endogenous constructs are statistically significant. Generally, this finding is supported and similar with other earlier studies [10], [48], [63], and contrary with finding of the study of [87].

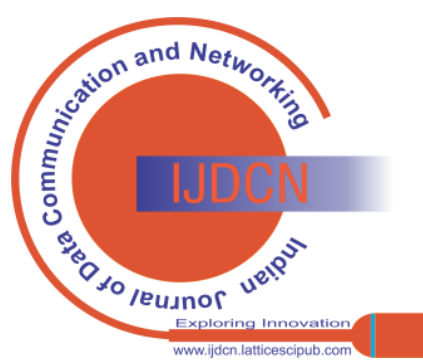


The result of this study carried out that the communication motive predicted the Facebook addiction, social interaction, and entertainment; and the interrelationship between the constructs is statistically significant. This finding supported by [88] who found that the correlations between communication and Facebook addiction is statistically significant; on the other hand this study is not similar with finding of [10] who founded that communication motive did not predict Facebook addiction; and have significant negative relationship with Facebook addiction [87]. Further, this confirms that the relationship between entertainment motive; and Facebook addiction and social interaction motive are positively significant, respectively. This finding is similar with previous studies that found entertainment to be a predictor of Facebook addiction and social interaction [10], [24], [68], [89], [90]. Social interaction motive positively predicted Facebook addiction. This is similar with previous literatures [10], and also contrary with [63] who found that social interaction motive did not predict Facebook addiction among her sampling.

As a conclusion, this study approve that BFAS is acceptable instrument to use SEM-PLS and has adequate properties in terms of converging and discernment validity, internal consistency and reliability. The most important contribution of the current study is to deliver and empirical evidence of increasing problem of Facebook addiction among youth engagement and students in Afghanistan. Based on the results, authors believe that the Facebook addiction is a phenomenon that exists across the countries, and greater use of Facebook would tend to create problem of addiction. Although, we suggest to service providers and policy makers that the young generation and students should be aware on any danger in terms of excessive user of social media, especially Facebook. Further, there is a need for appropriate academic agencies to do more research and focus on these emerging addiction problems associated with social media.

Limitations of study: This study has several limitations too. In this study, the data were collected by online survey via non probability sampling. It is recommended that in the future studies data should be collect through probability sampling and increase the sample size. In addition, the study focusing only on the motives as predictors of Facebook addiction, it-should be address any other moderating constructs to look at the moderation effects of demographic characteristics such as gender, level of study, academic performance and so on.

\section{ACKNOWLEDGMENT}

I would like to express my special thanks from Higher Education Development Project (HEDP), Ministry of Higher Education and Bamyan University for the valuable insights during the preparation of this manuscript

\section{REFERENCES}

1. A. Arrate, J. G. Cabanas, A. Cuevas, M. Calderon, and R. Cuevas, "Large-scale analysis of user exposure to online advertising on Facebook," IEEE Access, 2019.

2. P. Burger, S. Kanhai, A. Pleijter, and S. Verberne, "The reach of commercially motivated junk news on Facebook," ArXiv Prepr. ArXiv190107290, 2019. [CrossRef]
3. S. R. George, P. S. Kumar, and S. K. George, "Conceptual Framework Model for Opinion Mining for Brands in Facebook Engagements Using Machine Learning Tools," in ICT Analysis and Applications, Springer, 2020, pp. 115-121. [CrossRef]

4. L. Niu, "Using Facebook for Academic Purposes: Current Literature and Directions for Future Research," J. Educ. Comput. Res., vol. 56, pp. 1384-1406, Dec. 2017, doi: 10.1177/0735633117745161. [CrossRef]

5. S. F. I. Jaman and M. Anshari, "Facebook as marketing tools for organizations: Knowledge management analysis," in Dynamic perspectives on globalization and sustainable business in Asia, IGI Global, 2019, pp. 92-105. [CrossRef]

6. A. Peruta and A. B. Shields, "Marketing your university on social media: A content analysis of Facebook post types and formats," J. Mark. High. Educ., vol. 28, no. 2, pp. 175-191, 2018. [CrossRef]

7. R. Roopchund, V. Ramesh, and V. Jaunky, "Use of Social Media for Improving Student Engagement at Université des Mascareignes (UDM)," in Information Systems Design and Intelligent Applications, Springer, 2019, pp. 11-20. [CrossRef]

8. A. Teixeira and R. M. Laureano, "Data extraction and preparation to perform a sentiment analysis using open source tools: The example of a Facebook fashion brand page," in 2017 12th Iberian Conference on Information Systems and Technologies (CISTI), 2017, pp. 1-6. [CrossRef]

9. J. S. Barrot, "Facebook as a learning environment for language teaching and learning: A critical analysis of the literature from 2010 to 2017," $J$ Comput. Assist. Learn., vol. 34, no. 6, pp. 863-875, 2018. [CrossRef]

10. I. S. Y. Dhaha, "Predictors of Facebook addiction among youth: A structural equation modeling (SEM)," J. Soc. Sci. COESRJ-JSS, vol. 2 pp. 186-195, 2013.

11. F.-Y. Hong, D.-H. Huang, H.-Y. Lin, and S.-L. Chiu, "Analysis of the psychological traits, Facebook usage, and Facebook addiction model of Taiwanese university students," Telemat. Inform. vol. 31, no. 4, pp. 597-606, 2014. [CrossRef]

12. M. Koc and S. Gulyagci, "Facebook addiction among Turkish college students: The role of psychological health, demographic, and usage characteristics," Cyberpsychology Behav. Soc. Netw., vol. 16, no. 4, pp. 279-284, 2013. [CrossRef]

13. C. Marino, A. Vieno, M. Pastore, I. P. Albery, D. Frings, and M. M. Spada, "Modeling the contribution of personality, social identity and social norms to problematic Facebook use in adolescents," Addict. Behav., vol. 63, pp. 51-56, 2016. [CrossRef]

14. Z. Zaremohzzabieh, B. A. Samah, S. Z. Omar, J. Bolong, and N. A. ArXiv Prepr. ArXiv150801669, 2015. [CrossRef]

15. L. Z. Wise, J. Skues, and B. Williams, "Facebook in higher education promotes social but not academic engagement," Chang. Demands Chang. Dir. Proc. Ascilite Hobart, pp. 1332-1342, 2011.

16. F. Baltar and I. Brunet, "Social research 2.0: virtual snowball sampling method using Facebook," Internet Res., 2012. [CrossRef]

17. U. K. Rashid, O. Ahmed, and M. A. Hossain, "Relationship between Need for Belongingness and Facebook Addiction: Mediating Role of Number of Friends on Facebook," Int. J. Soc. Sci. Stud., vol. 7, no. 2, pp. 36-43, 2019. [CrossRef]

18. N. Dentchev et al., "Embracing the variety of sustainable business models: A prolific field of research and a future research agenda," $J$. Clean. Prod., vol. 194, pp. 695-703, 2018. [CrossRef]

19. M. Allen, "An education in Facebook," Digit. Cult. Educ., vol. 4, no. 3 , pp. 213-225, 2012.

20. K. Kalimeri, M. G. Beiró, A. Bonanomi, A. Rosina, and C. Cattuto, "Traditional versus Facebook-based surveys," Demogr. Res., vol. 42, pp. 133-148, 2020. [CrossRef]

21. C. Whitaker, S. Stevelink, and N. Fear, "The use of Facebook in recruiting participants for health research purposes: a systematic review," J. Med. Internet Res., vol. 19, no. 8, p. e290, 2017. [CrossRef]

22. S. E. Schoper and A. R. Hill, "Using Facebook to promote a virtual learning community: A case study," J. Learn. Spaces, vol. 6, no. 1, 2017.

23. I. T. Awidi, M. Paynter, and T. Vujosevic, "Facebook group in the learning design of a higher education course: An analysis of factors influencing positive learning experience for students," Comput. Educ., vol. 129, pp. 106-121, 2019. [CrossRef] 
24. B. Alzougool, "The impact of motives for Facebook use on Facebook addiction among ordinary users in Jordan," Int. J. Soc. Psychiatry, vol. 64, no. 6, pp. 528-535, 2018. [CrossRef]

25. S. Moghavvemi, M. Sharabati, T. Paramanathan, and N. M. Rahin, "The impact of perceived enjoyment, perceived reciprocal benefits and knowledge power on students' knowledge sharing through Facebook," Int. J. Manag. Educ., vol. 15, no. 1, pp. 1-12, 2017. [CrossRef]

26. Ş. Balci, "Facebook Addiction among University Students in Turkey: 'Selcuk University Example,"” p. 24.

27. R. Junco, "Student class standing, Facebook use, and academic performance," J. Appl. Dev. Psychol., vol. 36, pp. 18-29, 2015. [CrossRef]

28. B. W. Steggink, "Facebook addiction: Where does it come from? A study based on the Bergen Facebook Addiction Scale.," p. 30.

29. M. S. Uddin and A. A. Mamun, "Facebook Addiction Disorder: Is Facebook Really Addictive," Abnorm Behav Psychol, vol. 4, no. 135, pp. 2472-0496, 2018. [CrossRef]

30. E. Bergagna and S. Tartaglia, "Self-esteem, social comparison, and Facebook use," Eur. J. Psychol., vol. 14, no. 4, p. 831, 2018. [CrossRef]

31. D. Franz, H. E. Marsh, J. I. Chen, and A. R. Teo, "Using Facebook for qualitative research: a brief primer," J. Med. Internet Res., vol. 21, no. 8, p. e13544, 2019. [CrossRef]

32. A. Kumar and H. Syed, "Facebook as a Language Learning Environment: A Descriptive Study on ESL Learners' Perceptions,' Univ. Chitral J. Linguist. Lit., vol. 2, no. I, pp. 64-76, 2021.

33. A. N. Himat and H. R. Nazari, "AFGHAN STUDENTS'PURPOSES OF USING FACEBOOK AT MIRWAIS KHAN NIKA ZABUL INSTITUTE OF HIGHER EDUCATION, ZABUL, AFGHANISTAN," Am. Int. J. Soc. Sci. Res., vol. 6, no. 1, pp. 7-15, 2021. [CrossRef]

34. H. R. Ghulami, M. R. A. Hamid, M. R. Ibrahim, A. Hikmat, and H. Aziz, "Relationship between Internet addictions and academic performance among Afghan universities students," p. 10, 2018 [CrossRef]

35. M. R. Ibrahim and A. J. Hamdard, "THE WAYS OF SPENDING LEISURE TIME BY STUDENTS OF BAMYAN UNIVERSITY,' 2018.

36. H. R. Ghulami, M. R. A. Hamid, M. R. Ibrahim, A. Hikmat, and H. Aziz, "Relationship between Internet addictions and academic performance among Afghan universities students," Int. J. Innov. Res. Sci. Stud. IJIRSS, vol. 1, no. 4, 2018. [CrossRef]

37. S. N. Orfan, "Political participation of Afghan Youths on Facebook: A case study of Northeastern Afghanistan," Cogent Soc. Sci., vol. 7, no. 1, p. 1857916, 2021. [CrossRef]

38. M. N. Rahim, "The Relationship Between the Time Spent on Facebook and GPA Scores of Post-Graduates," Int. J. Multidiscip. Appl. Bus. Educ. Res., vol. 2, no. 1, pp. 94-102, 2021. [CrossRef]

39. F. Ataollah, A. Jafari, and S. Zarrabian, "Investigating the relationship between cyberspace addiction and emotional maturity in 20-30 years old female students," J. Adv. Pharm. Educ. Res. Oct-Dec, vol. 10, no. S4, 2020.

40. O. F. Alabi, "A survey of Facebook addiction level among selected Nigerian University undergraduates," New Media Mass Commun., vol. 10, no. 2012, pp. 70-80, 2013.

41. L. B. Beiler, "The Relationship between Facebook Addiction Indicators and Communication Characteristics in IGeneration College Students,' Ph.D., Grand Canyon University, United States -- Arizona, 2020.

42. Ç. Yaman, "Facebook Addiction Levels of Students in the Physical Education and Sport Department.," Malays. Online J. Educ. Technol., vol. 4, no. 2, pp. 1-7, 2016.

43. A. B \lachnio, A. Przepiórka, and A. Cudo, "The relations between Facebook intrusion, emotional functioning, and health problems," Curr. Psychol., pp. 1-13, 2021. [CrossRef]

44. V. Balakrishnan and A. Shamim, "Malaysian Facebookers: Motives and addictive behaviours unraveled," Comput. Hum. Behav., vol. 29, no. 4 , pp. 1342-1349, 2013. [CrossRef]

45. L. D. Rosen, K. Whaling, S. Rab, L. M. Carrier, and N. A. Cheever, "Is Facebook creating 'iDisorders'? The link between clinical symptoms of psychiatric disorders and technology use, attitudes and anxiety," Comput. Hum. Behav., vol. 29, no. 3, pp. 1243-1254, 2013. [CrossRef]

46. H. M. Pontes, M. Taylor, and V. Stavropoulos, "Beyond 'Facebook addiction': The role of cognitive-related factors and psychiatric distress in social networking site addiction," Cyberpsychology Behav. Soc. Netw., vol. 21, no. 4, pp. 240-247, 2018. [CrossRef]

47. C. Fleuriet, M. Cole, and L. K. Guerrero, "Exploring Facebook: Attachment style and nonverbal message characteristics as predictors of anticipated emotional reactions to Facebook postings," J. Nonverbal Behav., vol. 38, no. 4, pp. 429-450, 2014. [CrossRef]

48. A. B \lachnio, A. Przepiorka, E. Senol-Durak, M. Durak, and L. Sherstyuk, "The role of personality traits in Facebook and Internet addictions: A study on Polish, Turkish, and Ukrainian samples,' Comput. Hum. Behav., vol. 68, pp. 269-275, 2017. [CrossRef]

49. C. Abrahamsson, The advantages of social capital for businesses on Facebook. 2017.

50. Z. Senin, S. Mohamad, I. S. Hassana, and R. Hasan, "Facebook Integration in Teaching and Learning at Politeknik Port Dickson," PROCEEDING Innov. Res. Sci. Technol. Cult. IRSTC, pp. A33-A36, 2020.

51. B. Kim and Y. Kim, "Facebook versus Instagram: How perceived gratifications and technological attributes are related to the change in social media usage," Soc. Sci. J., vol. 56, no. 2, pp. 156-167, 2019 [CrossRef]

52. C.-B. Zhang, Y.-N. Li, B. Wu, and D.-J. Li, "How WeChat can retain users: Roles of network externalities, social interaction ties, and perceived values in building continuance intention," Comput. Hum Behav., vol. 69, pp. 284-293, 2017. [CrossRef]

53. J. Phua, S. V. Jin, and J. J. Kim, "Uses and gratifications of social networking sites for bridging and bonding social capital: A comparison of Facebook, Twitter, Instagram, and Snapchat," Comput. Hum. Behav., vol. 72, pp. 115-122, 2017. [CrossRef]

54. U. B. Gezgin, "E-Bağlantıda Ol': Kișilikve Facebook Kullanımı," Akdeniz Üniversitesi Illetişim Fakültesi Derg., no. 18, pp. 123-139.

55. N. L. Young, D. J. Kuss, M. D. Griffiths, and C. J. Howard, "Passive Facebook use, Facebook addiction, and associations with escapism: An experimental vignette study," Comput. Hum. Behav., vol. 71, pp 24-31, 2017. [CrossRef]

56. C. Pribeanu, "Using the Consumption Values Theory to Analyze the Relationship between the Motives for Facebook Use and Its Perceived Usefulness for University Students," Inform. Econ., vol. 24, no. 2, pp. 5-14, 2020. [CrossRef]

57. M. Kim and J. Cha, "A comparison of Facebook, Twitter, and LinkedIn: Examining motivations and network externalities for the use of social networking sites," First Monday, 2017.

58. K. C. Fernandez, C. A. Levinson, and T. L. Rodebaugh, "Profiling Predicting social anxiety from Facebook profiles," Soc. Psychol. Personal. Sci., vol. 3, no. 6, pp. 706-713, 2012. [CrossRef]

59. A. Shensa, J. E. Sidani, M. A. Dew, C. G. Escobar-Viera, and B. A. Primack, "Social Media Use and Depression and Anxiety Symptoms: A Cluster Analysis," Am. J. Health Behav., vol. 42, no. 2, pp. 116-128, 2018. [CrossRef]

60. D. Zendle and H. Bowden-Jones, Is excessive use of social media an addiction? British Medical Journal Publishing Group, 2019. [CrossRef]

61. V. Franchina and G. L. Coco, "The influence of social media use on body image concerns," Int. J. Psychoanal. Educ., vol. 10, no. 1, pp. 5-14 2018.

62. B. L. Curtis, S. J. Lookatch, D. E. Ramo, J. R. McKay, R. S. Feinn, and H. R. Kranzler, "Meta-Analysis of the Association of Alcohol-Related Social Media Use with Alcohol Consumption and Alcohol-Related Problems in Adolescents and Young Adults," Alcohol. Clin. Exp. Res., vol. 42, no. 6, pp. 978-986, 2018. [CrossRef]

63. S. S. SZ, S. Z. Omar, J. Bolong, and M. N. Osman, "Facebook addiction among female university students," Rev. Adm. Publica Si Polit. Soc. vol. 3, no. 7, p. 95, 2011.

64. [64] A. R. Teo, B. K. Chan, S. Saha, and C. Nicolaidis, "Frequency of social contact in-person vs. on Facebook: An examination of associations with psychiatric symptoms in military veterans," J. Affect. Disord., vol. 243, pp. 375-380, 2019. [CrossRef]

65. B. Alzougool, "Facebook Addiction among Ordinary Users in Jordan," in ECSM 2018 5th European Conference on Social Media, 2018, p. 1

66. P. Capriotti and J.-C. Losada-Díaz, "FACEBOOK AS A DIALOGIC COMMUNICATION TOOL AT THE MOST VISITED MUSEUMS OF THE WORLD.," El Prof. Inf., vol. 27, no. 3, 2018. [CrossRef]

67. M. Eriksson and E.-K. Olsson, "Facebook and Twitter in crisis communication: A comparative study of crisis communication professionals and citizens," J. Contingencies Crisis Manag., vol. 24, no. 4, pp. 198-208, 2016. [CrossRef]

68. J. Stephenson, M. Vaganay, D. Coon, R. Cameron, and N. Hewitt, "The role of Facebook and Twitter as organisational communication platforms in relation to flood events in Northern Ireland," J. Flood Risk Manag., vol. 11, no. 3, pp. 339-350, 2018. [CrossRef]

69. L. P. Tosun, "Motives for Facebook use and expressing 'true self' on the Internet," Comput. Hum. Behav., vol. 28, no. 4, pp. 1510-1517, 2012. [CrossRef]

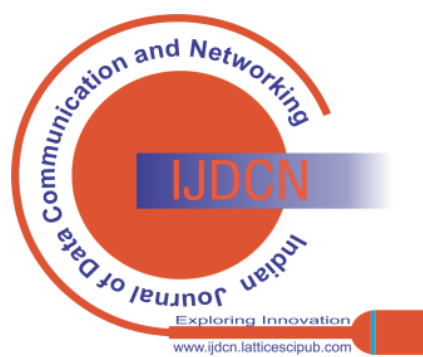


70. I. Abbasi and M. Drouin, "Neuroticism and Facebook addiction: How social media can affect mood?," Am. J. Fam. Ther., vol. 47, no. 4, pp. 199-215, 2019. [CrossRef]

71. A. Zia, M. Hussain, and Z. Yasin, "Educational Motives and Perceived Educational Consequences as Predictors of Facebook Usage," J. Media Stud., vol. 35, no. 2, 2020.

72. G. F. da Veiga, L. Sotero, H. M. Pontes, D. Cunha, A. Portugal, and A. P. Relvas, "Emerging adults and Facebook use: the validation of the Bergen Facebook Addiction Scale (BFAS)," Int. J. Ment. Health Addict., vol. 17, no. 2, pp. 279-294, 2019. [CrossRef]

73. H. Jafarkarimi, A. T. H. Sim, R. Saadatdoost, and J. M. Hee, "Facebook addiction among Malaysian students," Int. J. Inf. Educ. Technol., vol. 6 , no. 6, p. 465, 2016. [CrossRef]

74. I. Ozer, "Facebook addiction, intensive social networking site use, multitasking, and academic performance among university students in the United States, Europe, and Turkey: A multigroup structural equation modeling approach,” Ph.D., Kent State University, United States -- Ohio, 2014.

75. J. F. Hair, C. M. Ringle, and M. Sarstedt, "PLS-SEM: Indeed a silver bullet," J. Mark. Theory Pract., vol. 19, no. 2, pp. 139-152, 2011. [CrossRef]

76. C. M. Ringle, M. Sarstedt, R. Mitchell, and S. P. Gudergan, "Partial leas squares structural equation modeling in HRM research," Int. J. Hum. Resour. Manag., vol. 31, no. 12, pp. 1617-1643, 2020. [CrossRef

77. R. Scherer, F. Siddiq, and J. Tondeur, "The technology acceptance model (TAM): A meta-analytic structural equation modeling approach to explaining teachers' adoption of digital technology in education,' Comput. Educ., vol. 128, pp. 13-35, 2019. [CrossRef]

78. L. Shahnaz, "Profiling Facebook users among KIRKHS students and their motives for using Facebook," Master's Thesis, Kuala Lumpur: International Islamic University Malaysia, 2011, 2011.

79. B. Anderson, P. Fagan, T. Woodnutt, and T. Chamorro-Premuzic, "Facebook psychology: Popular questions answered by research.," Psychol. Pop. Media Cult., vol. 1, no. 1, p. 23, 2012. [CrossRef]

80. J. F. Hair, W. C. Black, B. J. Babin, and R. E. Anderson, "Canonical correlation: A supplement to multivariate data analysis," Multivar. Data Anal. Glob. Perspect. 7th Edn Pearson Prentice Hall Publ. Up. Saddle River, 2010.

81. T. Ramayah, J. A. Yeap, N. H. Ahmad, H. A. Halim, and S. A. Rahman, "Testing a confirmatory model of Facebook usage in SmartPLS using consistent PLS," Int. J. Bus. Innov., vol. 3, no. 2, pp. 1-14, 2017.

82. J. Henseler, C. M. Ringle, and M. Sarstedt, "A new criterion for assessing discriminant validity in variance-based structural equation modeling,” J. Acad. Mark. Sci., vol. 43, no. 1, pp. 115-135, 2015. [CrossRef]

83. J. F. Hair, W. C. Black, B. J. Babin, and R. E. Anderson, "Multivariate Data Analysis: A Global Perspective, 7th edn (Uppersaddle River, NJ: Pearson Prentice Hall)," 2010.

84. M. R. Ab Hamid, W. Sami, and M. M. Sidek, "Discriminant validity assessment: Use of Fornell \& Larcker criterion versus HTMT criterion,' in Journal of Physics: Conference Series, 2017, vol. 890, no. 1, p. 012163. [CrossRef]

85. H. R. Ghulami, M. R. A. Hamid, and ZAKARIA, Rslinzairimh, "Partial least squares modelling of attitudes of students towards learning statistics," J Qual Meas Anal JQMA, vol. 10, no. 1, pp. 1-16, 2014.

86. C. Fornell and D. F. Larcker, "Evaluating structural equation models with unobservable variables and measurement error," J. Mark. Res., vol 18, no. 1, pp. 39-50, 1981. [CrossRef]

87. M. H. Ahamad and B. C. Das, "Facebook Addiction among College going Students: An Exploratory Study in Patuakhali District of Bangladesh," Soc. Sci. Humanit. J., vol. 2, no. 10, pp. 617-623, 2018.

88. S. S. SZ, S. Z. Omar, J. Bolong, and M. N. Osman, "Facebook addiction among female university students," Rev. Adm. Publica Si Polit. Soc., vol. 3, no. 7, p. 95, 2011.

89. J. Kim and P. M. Haridakis, "The role of Internet user characteristics and motives in explaining three dimensions of Internet addiction," $J$. Comput.-Mediat. Commun., vol. 14, no. 4, pp. 988-1015, 2009. [CrossRef]

90. S. Moghavvemi, A. Sulaiman, A. A. Aziz, and P. S. Wai, "The impact of Facebook usage on academic performance," in 2017 International Conference on Research and Innovation in Information Systems (ICRIIS), 2017, pp. 1-5. [CrossRef]

\section{AUTHORS PROFILE}

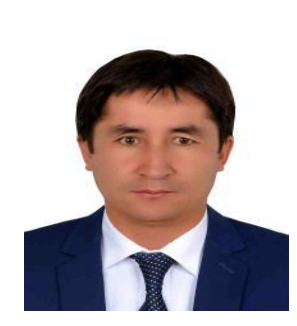

Hassan Rahnaward Ghulami, graduated as Master of Science (Statistics) from University Malaysia Pahang (UMP), and got bachelor degree in pure Mathematics from Kabul University. Published three journal papers which are indexed Scopus, and participated in three conference proceeding. My poster presentation entitled "Students Attitudes towards learning of statistics: A case study in UMP" in Creation, Innovation, Technology \& Research Exposition (CITREX)" received bronze medal and although my paper entitled "Relationship between Internet addictions and academic performance among Afghan universities students" awarded the best paper. Since 2005, appointed as senior lecturer, dean of research committee in the faculty of natural science, editor in Chief: Scientific- Research journal of Bamyan University.

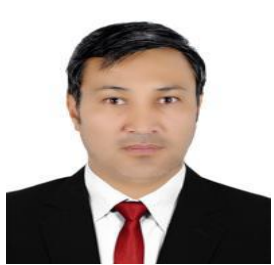

Abdul Samad Roesh, Master of Education \&amp; Extension | April 2011 | University of Pune India Dissertation title: "A study of Difficulties learning Physics at Junior College Level in Pune city. BSc in (General physics) from Kabul Education University Graduation completed on Dec 2005. Worked as vice chancellor of Bamyan University, senior lecturer and dean of Natural science faculty. Editor in Chief: Scientific- Research journal, Member of Editorial Board Scientific- Research journal of Bamyan University, Member of (APR) Academic program Review National Committee in ministry of Higher Education- Afghanistan, and member of curriculum update National Committee in ministry of Higher Education

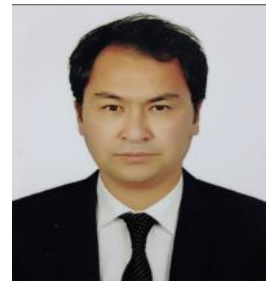

Mohammad Reza Ibrahim, Master of Art (HNRS) Human and Natural Resource Studies Center, School of Arts, Kathmandu University Nepal. B.A. Dept. of Sociology and philosophy, Faculty of social science, Kabul university, Afghanistan Worked as vice chancellor of Bamyan University, senior lecturer and head of sociology department, faculty of sociology. Published three scientific research paper in international journal. A Sociological Review of Terrorism: Scientific -Research Journal of Bamyan University and member of Editorial Board Scientific- Research journal of Bamyan University, Member of (APR) Academic program Review National Committee in ministry of Higher Education- Afghanistan, and member of External Peer Reviewers of Ministry of Higher Education.

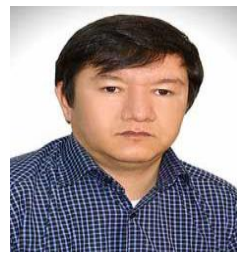

Mohammad Akbari, Bachelor degree in Mathematics department from Kabul Education University, Afghanistan. Master degree in applied Mathematics from Imam Khumaini International University, Iran. Published 5 papers Bamyan university journal one article have published in Knowvel Journls. Senior lecturer and head of Mathematics in Bamyan University.

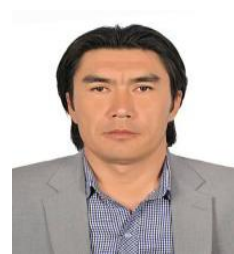

Dr. Hossein Mohammadi, UKM, Faculty of Science and Technology, Kuala Lumpur, Malaysia, Ph.D in Agriculture; UAS, GKVK, Agronomy Department, Bangalore, India. (Master's Degree in Agriculture), Kabul University, Agricultural faculty, Agronomy Department, Kabul, Afghanistan, Bachelor's Degree in Agronomy. Published four journal paper internationally and three paper have published in the journal of Bamyan university. Achievement: awarded Bachelor Certificate, Master Certificate and PhD Certificate

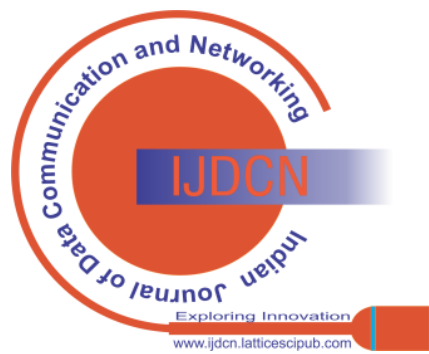

